\title{
Microvascular dysfunction as a link between obesity, insulin resistance and hypertension
}

Citation for published version (APA):

Karaca, U., Schram, M. T., Houben, A. J. H. M., Muris, D. M. J., \& Stehouwer, C. D. A. (2014).

Microvascular dysfunction as a link between obesity, insulin resistance and hypertension. Diabetes

Research and Clinical Practice, 103(3), 382-387. https://doi.org/10.1016/j.diabres.2013.12.012

Document status and date:

Published: 01/03/2014

DOI:

10.1016/j.diabres.2013.12.012

Document Version:

Publisher's PDF, also known as Version of record

Document license:

Taverne

\section{Please check the document version of this publication:}

- A submitted manuscript is the version of the article upon submission and before peer-review. There can be important differences between the submitted version and the official published version of record.

People interested in the research are advised to contact the author for the final version of the publication, or visit the DOI to the publisher's website.

- The final author version and the galley proof are versions of the publication after peer review.

- The final published version features the final layout of the paper including the volume, issue and page numbers.

Link to publication

\footnotetext{
General rights rights.

- You may freely distribute the URL identifying the publication in the public portal. please follow below link for the End User Agreement:

www.umlib.nl/taverne-license

Take down policy

If you believe that this document breaches copyright please contact us at:

repository@maastrichtuniversity.nl

providing details and we will investigate your claim.
}

Copyright and moral rights for the publications made accessible in the public portal are retained by the authors and/or other copyright owners and it is a condition of accessing publications that users recognise and abide by the legal requirements associated with these

- Users may download and print one copy of any publication from the public portal for the purpose of private study or research.

- You may not further distribute the material or use it for any profit-making activity or commercial gain

If the publication is distributed under the terms of Article $25 \mathrm{fa}$ of the Dutch Copyright Act, indicated by the "Taverne" license above, 


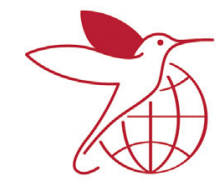

International

Diabetes

Federation

\title{
Invited Review
}

\section{Microvascular dysfunction as a link between obesity, insulin resistance and hypertension}

\author{
Ü. Karaca, M.T. Schram, A.J.H.M. Houben*, D.M.J. Muris, \\ C.D.A. Stehouwer
}

Department of Internal Medicine and Cardiovascular Research Institute Maastricht (CARIM), Maastricht University Medical Centre (MUMC), Maastricht, The Netherlands

\section{A R T I C L E I N F O}

\section{Article history:}

Received 18 December 2013

Received in revised form

18 December 2013

Accepted 18 December 2013

Available online 25 December 2013

Keywords:

Microvascular dysfunction

Obesity

Insulin resistance

Hypertension

\begin{abstract}
A B S T R A C T
Impaired microvascular dilatation from any cause and impaired insulin-mediated capillary recruitment in particular result in suboptimal delivery of glucose and insulin to skeletal muscle, and subsequently impairment of glucose disposal (insulin resistance). In addition, microvascular dysfunction, through functional and/or structural arteriolar and capillary drop-out, and arteriolar constriction, increases peripheral resistance and thus blood pressure. Microvascular dysfunction may thus constitute a pathway that links insulin resistance and hypertension. Overweight and obesity may be an important cause of microvascular dysfunction. Mechanisms linking overweight and obesity to microvascular dysfunction include changes in the secretion of adipokines leading to increased levels of free fatty acids and inflammatory mediators, and decreased levels of adiponectin all of which may impair endothelial insulin signaling. Microvascular dysfunction may thus constitute a new treatment target in the prevention of type 2 diabetes mellitus and hypertension.
\end{abstract}

(C) 2014 Elsevier Ireland Ltd. All rights reserved.

\section{Contents}

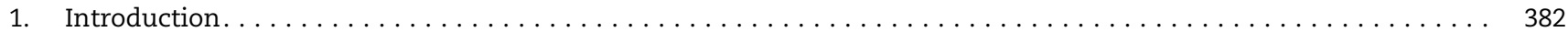

2. Definition and measurement of microvascular function $\ldots \ldots \ldots \ldots \ldots \ldots \ldots \ldots \ldots$

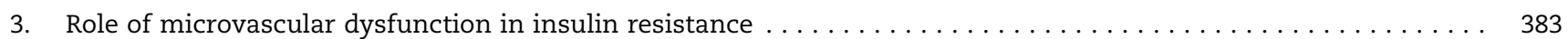

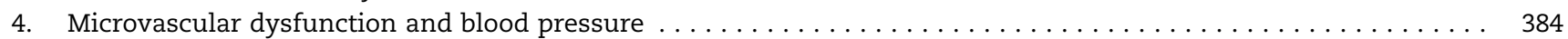

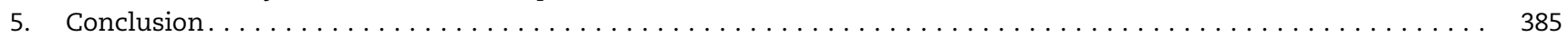

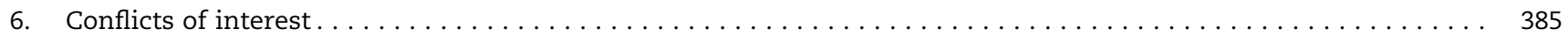

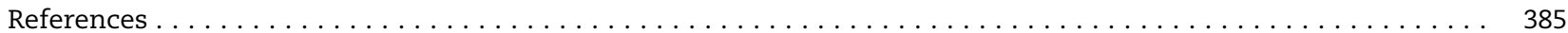

\section{Introduction}

Diabetes is a pandemic disease characterized by a number of metabolic abnormalities as a result from defects in insulin secretion and/or insulin action. About 366 million people worldwide have diabetes and this is expected to rise to $\sim 552$ million people in the next 20 years (www.idf.org). More than $90 \%$ of these patients have type 2 diabetes (www.who.int). Insulin resistance (i.e. impaired insulin-mediated glucose

\footnotetext{
* Corresponding author at: Maastricht University Medical Centre, Department of Internal Medicine, P.O. Box 5800, 6202 AZ Maastricht, The Netherlands.

E-mail address: b.houben@maastrichtuniversity.nl (A.J.H.M. Houben). 0168-8227/\$ - see front matter (C) 2014 Elsevier Ireland Ltd. All rights reserved. http://dx.doi.org/10.1016/j.diabres.2013.12.012
} 
disposal) plays an important role in the development of type 2 diabetes (T2DM). Emerging data suggest that microvascular dysfunction is an important contributor to the pathogenesis of insulin resistance, and may thus constitute a new treatment target in the prevention of T2DM.

Classically, microvascular dysfunction is regarded as a consequence of T2DM, expressing itself in diabetes-related microvascular complications such as retinopathy, nephropathy, and neuropathy. More recently, studies have demonstrated that microvascular dysfunction may also act as a precursor of insulin resistance and T2DM [1,2]. Impaired microvascular dilatation from any cause and impaired insulin-mediated capillary recruitment in particular result in suboptimal delivery of glucose and insulin to skeletal muscle, and subsequently impairment of glucose disposal. In addition, microvascular dysfunction, through functional and/ or structural arteriolar and capillary drop-out (so-called rarefaction), and arteriolar constriction, increases peripheral resistance. Microvascular dysfunction is thus thought to play a role in the development of high blood pressure, which often accompanies insulin resistance. Taken together, microvascular dysfunction has been identified both as an antecedent of insulin resistance [3] and to contribute to the development of high blood pressure [4].

\section{Definition and measurement of microvascular function}

The microcirculation represents the smallest structural and functional units of the cardiovascular system and is composed of a network of blood vessels less than $150 \mu \mathrm{m}$ in diameter including arterioles, capillaries, and venules. The microcirculation is an important part of the cardiovascular system because it regulates organ perfusion, vascular tone, and transendothelial transport of blood solutes [5,6]. Arterioles consist of endothelial cells surrounded by a layer of smooth muscle cells and play an important role in the local distribution of blood to and within tissues, and also in the regulation of peripheral resistance. More than $90 \%$ of all blood vessels of the human body consist of capillaries. Capillaries in turn consist of a single layer of endothelial cells, without a muscle layer. Exchange of nutrients, water and gases takes place at this capillary level. Venules also consist of endothelial cells surrounded by a smooth muscle layer, and they regulate capillary pressure in addition to outflow. Impairment in at least one of the above functions constitutes microvascular dysfunction.

Several methods are available to measure microvascular (dys) function noninvasively. First, assessment of microvascular function in specific microvascular beds is frequently used, such as in (1) skin (by capillaroscopy and laser-Doppler fluxmetry) [4,7-10]; (2) muscle (by plethysmography and contrast-enhanced ultrasonography) [11,12]; (3) bulbar conjunctival bed (by intravital microscopy) [13,14]; and (4) retina (by photography) [15-18]. Besides baseline measurements, stimulus-induced responses can be used to determine microvascular (endothelium- or non-endothelium-dependent) reactivity. Among such stimuli are local ischemia, heating, or local or systemic administration of endothelium-(in)dependent vasoactive agents (e.g. acetylcholine and sodium nitroprusside)
$[4,10,19]$. Second, microvascular function, in particular endothelial function, can be assessed with the use of plasma biomarkers because the large surface area and production capacity of the microcirculation (i.e. $98 \%$ of the total vascular surface area [20]) makes it likely that higher circulating concentrations of endothelial biomarkers reflect predominantly microvascular (rather than macrovascular) endothelial function. Measurements of plasma levels of endotheliumderived regulatory proteins such as soluble E-selectin (sEselectin), soluble intercellular adhesion molecule 1 (sICAM-1), soluble vascular adhesion molecule 1 (sVCAM-1), and von Willebrand factor (vWF) [21] are often used. Increased levels of these markers are thought to reflect endothelial permeability to leucocytes (i.e. sE-selectin, sICAM-1, and SVCAM-1) [22-25], and prothrombotic and procoagulant activity (i.e. vWF) [23-25]. In addition, slight increases in urinary albumin excretion, socalled microalbuminuria, are thought to reflect a generalized increase in endothelial permeability [23], and is frequently used as a marker of general endothelial dysfunction [23-28]. Several studies have confirmed the concept that microalbuminuria is associated with a greater transcapillary escape rate of albumin, i.e. with greater microvascular permeability, and also showed that microalbuminuria, as a marker of endothelial function, is associated with risk of cardiovascular disease [23]. In addition, such associations cannot be explained by conventional risk factors.

\section{Role of microvascular dysfunction in insulin resistance}

Insulin promotes its own delivery and that of glucose to skeletal muscles by inducing microvascular vasodilation and capillary recruitment. It has been shown that this microvascular action of insulin accounts for $\sim 40 \%$ of insulinstimulated muscle glucose uptake $[29,30]$. Thus, microvascular dysfunction may lead to suboptimal delivery of plasma insulin and glucose to skeletal muscle cells. In the 1990s, Baron and colleagues first reported insulin's ability to vasodilate resistance vessels and consequently increase total skeletal muscle blood flow [3], which is paralleled by an increase in insulin-mediated glucose uptake [31,32]. Most studies on the vascular action of insulin observed only insulin-mediated increases in total limb blood flow after using supra-physiological doses of insulin or after several hours of delay when physiological concentrations were used $[11,33]$. Hence, the physiological importance of insulin's ability to increase total blood flow remains controversial [34]. Nevertheless, insulin has subsequently been shown to redirect blood flow in skeletal muscle from non-nutritive to nutritive capillary networks (capillary recruitment), without increasing total muscle blood flow. These effects are followed by an increase in insulinmediated glucose uptake [35]. Such capillary recruitment requires physiological concentrations of insulin and has a time course that accords well with the time course for insulinmediated glucose uptake in skeletal muscle [36]. Moreover, this process has been shown to be endothelium-dependent, requiring activation of the PI3-kinase pathway in the endothelial cell [37] resulting in endothelial nitric oxide synthase (eNOS) activation and production of nitric oxide 
(NO). Consequently, insulin-induced increase in NO production stimulates capillary recruitment $[38,39]$ and transendothelial transport of insulin [40]. On the other hand, insulin also has vasoconstrictor effects in endothelial cells involving the MAP kinase pathway and resulting in the production of endothelin-1 (ET-1) [37]. Under physiological conditions, when insulin binds to the insulin or insulin-like growth factor receptor on endothelial cells [41], the net result usually favors NO production [38] and thus vasodilatation and capillary recruitment. Prospective studies support the hypothesis that microvascular dysfunction precedes and even predicts the development of T2DM, as these studies show that microvascular dysfunction is associated with incident impaired fasting glucose (IFG) and incident T2DM [1,42]. Recently, Muris et al. pooled thirteen prospective population-based studies in a meta-analysis, and concluded that the risks for incident T2DM was 25\% higher per 1 SD greater microvascular dysfunction (as measured with plasma markers of endothelial function (sE-selectin, sICAM-1, sVCAM-1, and vWF), retinal microvessels, peripheral vascular reactivity, and microalbuminuria) in a follow-up period ranging from 2.6 to 12 years [1]. In the same meta-analysis, retinal microvasculature was also associated with risk for incident impaired fasting glucose (IFG). One SD greater retinal venular diameters were associated with a 15\% higher incidence of IFG, and one SD lower arteriolar-to-venular ratio (AVR) was associated with $14 \%$ higher incidence of IFG. In addition, in animals with diet-induced insulin resistance it was demonstrated that microvascular endothelial dysfunction develops well before impaired insulin activation of PI3K in skeletal muscle [43]. All these data strongly suggest that microvascular dysfunction is a cause of insulin resistance, by affecting insulinmediated glucose uptake in skeletal muscle through impaired capillary recruitment.

Overweight and obesity may be an important cause of microvascular dysfunction. Studies in obese subjects described diminished skin capillary recruitment [44]. And impaired capillary recruitment has been shown to be inversely associated with visceral adiposity and truncal subcutaneous adipose tissue [45]. Mechanisms linking overweight and obesity to microvascular dysfunction include changes in the secretion of adipokines leading to increased levels of free fatty acids and inflammatory mediators, and decreased levels of adiponectin [46], all of which may impair endothelial insulin signaling $[47,48]$. Apart from visceral adipose tissue, perivascular adipose tissue (PVAT) may play a role in microvascular dysfunction $[48,49]$. Under normal circumstances, adiponectin release from PVAT enhances insulin's vasodilator effects in a paracrine fashion, whereas in the $d b / d b$ mice, an increased PVAT and reduced adiponectin release was demonstrated, which was associated with decreased insulin-mediated vasodilation [50]. In conclusion, both systemic and local adipose tissue derived agents seem to contribute to the development of microvascular dysfunction through impairing insulin signaling pathways.

\section{Microvascular dysfunction and blood pressure}

Impaired microvascular function and structure is generally accepted as a consequence of high $\mathrm{BP}$, but there is also evidence that microvascular changes, i.e. capillary rarefaction, may antedate the clinical onset of high BP [4]. All components of the microcirculation contribute to some extent to peripheral resistance. Small arteries and arterioles amount to $40-45 \%$ of total peripheral resistance, capillaries up to $23-$ $30 \%$, and the venules up to 3-4\% [51]. Decreased capillary density may contribute to increased peripheral resistance, subsequently resulting in an increase in BP [52]. In a mathematical model based on the hamster cheek pouch microcirculation, functionally removing microvessels resulted in an elevation in vascular resistance [53]. Crosssectional studies indeed demonstrated that skin capillary density was 10-20\% lower in subjects with untreated hypertension as compared to normotensive controls [4,54]. In a longitudinal study of untreated hypertensive subjects, a low muscle capillary density at baseline was associated with an increase in mean arterial pressure during 20 years followup [55]. Also, the fact that decreased capillary density has been found in borderline hypertensive subjects [56] and even in normotensive offspring of hypertensive parents [57] also supports the concept that microvascular dysfunction may precede the development of hypertension. On the one hand, capillary rarefaction may be a structural phenomenon as in subjects with low birth weight. In prepubertal children (born at term), it was shown that lower birth weight was associated with decreased capillary recruitment [58]. On the other hand, capillary rarefaction may be a functional phenomenon [4] potentially related to impaired insulin-mediated microvascular actions. Besides the effects of capillary rarefaction, reduced arteriolar diameter (due to increased vasoconstriction and/or a thickened arteriolar wall) also contributes to the development of high blood pressure. Several longitudinal human studies have demonstrated that retinal arteriolar narrowing in normotensive subjects is independently associated with the development of high BP during a 3-6.6 years follow-up [59-62]. Part of this retinal arteriolar narrowing may be functional as flicker-light induced retinal arteriolar vasodilation, a response partly dependent on NO [63], was reduced in subjects with untreated hypertension as compared with normotensive subjects, suggesting that functional defects are also present in untreated hypertension [64]. In addition, the fact that anti-hypertensive treatment in previously untreated hypertensive subjects improves skin microvascular function adds to the concept that these (early) changes are functional [65]. Also, a prospective study in subjects with obesity showed that pre-surgical impaired microvascular function, as measured with laser-Doppler fluxmetry, was fully normalized 1 year after a gastric bypass surgery, and was also associated with a decrease in BP [66]. Taken together, these data suggest that microvascular dysfunction, represented as rarefaction and/or arteriolar constriction, contributes to the development of high BP.

Once hypertension has become manifest, high BP may also contribute to (further) deterioration of microvascular dysfunction. Increases in BP results in remodeling of the resistance arterioles because of changes in circumferential wall stress $[51,67]$. Vascular remodeling refers to alterations in structure of resistance vessels and can be classified as hypertrophic, hypotrophic, or eutrophic remodeling. In the eutrophic situation, changes of the vessel wall will occur without 


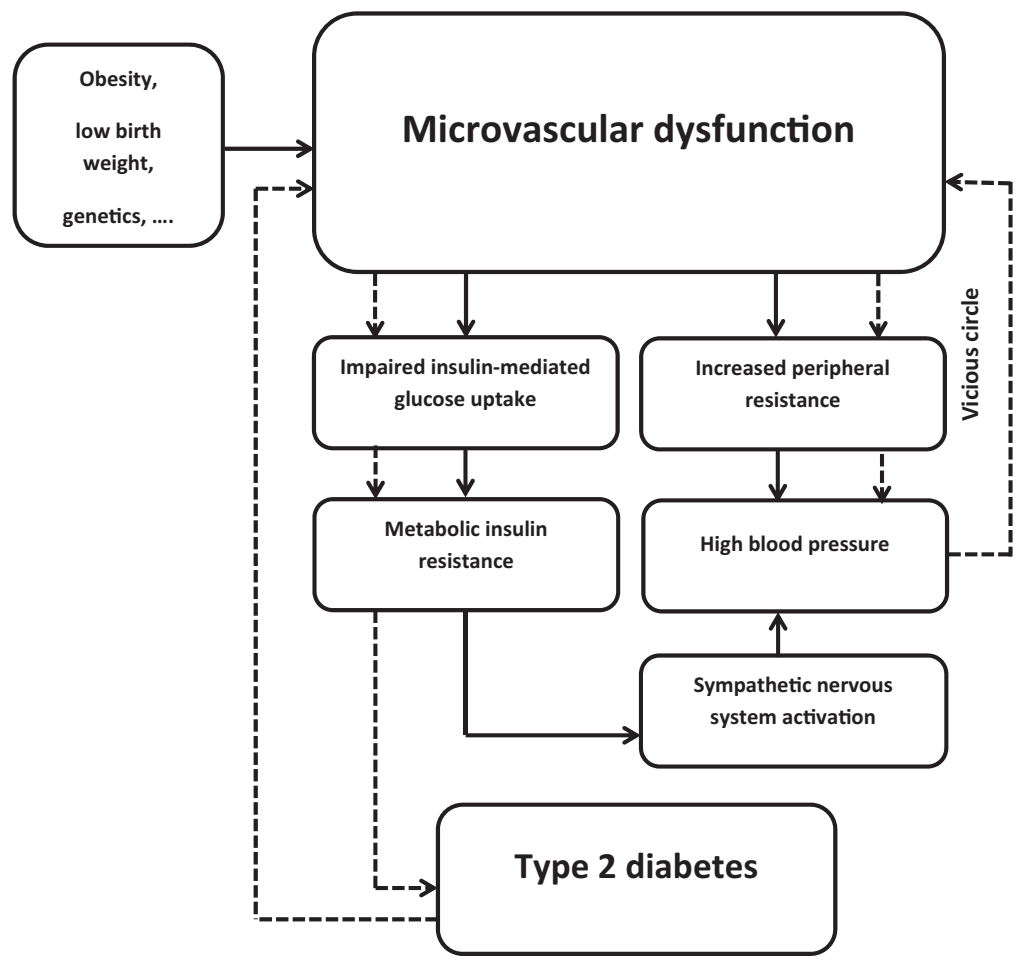

Fig. 1 - Hypothesis: contribution of microvascular dysfunction to insulin resistance, type 2 diabetes and hypertension.

changes in the amount or characteristics of wall material. On the other hand, the amount of wall material can increase (hypertrophic remodeling) or decrease (hypotrophic remodeling) [68]. Changes in vessel wall composition can lead to an increase or decrease in vessel wall diameter (inward or outward remodeling). In individuals with hypertension, structural changes of the microvessels result in reduced lumen diameter and increased media-to-lumen ratio. These vascular changes can be classified as inward eutrophic remodeling [69], and can result in higher peripheral resistance $[67,70]$. Thus, high BP and microvascular dysfunction form a vicious circle in which both mechanisms reinforce each other.

\section{Conclusion}

Taken together, all these data suggest that microvascular dysfunction is a linking factor between insulin resistance and high BP (Fig. 1). We hypothesize that microvascular dysfunction contributes to type 2 diabetes through insulin resistance, and that microvascular dysfunction in addition contributes to the development of hypertension. Therefore, microvascular dysfunction may be a target in the prevention and treatment of insulin resistance, (pre)diabetes, and high BP. Obesity is associated with impaired microvascular function, but more studies are required to unravel the exact pathophysiological pathways that link obesity to microvascular dysfunction.

\section{Conflicts of interest}

The authors declare that they have no conflict of interest.

\section{R E F E R E N C E S}

[1] Muris DMJ, Houben AJHM, Schram MT, Stehouwer CDA. Microvascular dysfunction is associated with a higher incidence of type 2 diabetes mellitus: a systematic review and meta-analysis. Arterioscler Thromb Vasc Biol 2012;32:3082-94.

[2] Jonk AM, Houben AJHM, de Jongh RT, Serne EH, Schaper NC, Stehouwer CDA. Microvascular dysfunction in obesity: a potential mechanism in the pathogenesis of obesityassociated insulin resistance and hypertension. Physiology (Bethesda) 2007;22:252-60.

[3] Baron AD. Hemodynamic actions of insulin. Am J Physiol 1994;267:E187-202.

[4] Serne EH, Gans RO, ter Maaten JC, Tangelder GJ, Donker AJ, Stehouwer CD. Impaired skin capillary recruitment in essential hypertension is caused by both functional and structural capillary rarefaction. Hypertension 2001;38: 238-42.

[5] Levy BI, Ambrosio G, Pries AR, Struijker-Boudier HA. Microcirculation in hypertension: a new target for treatment. Circulation 2001;104:735-40.

[6] Verdant C, De Backer D. How monitoring of the microcirculation may help us at the bedside. Curr Opin Crit Care 2005;11:240-4.

[7] Rossi M, Carpi A, Galetta F, Franzoni F, Santoro G. Skin vasomotion investigation: a useful tool for clinical evaluation of microvascular endothelial function. Biomed Pharmacother 2008;62:541-5.

[8] Roustit M, Cracowski J-L. Assessment of endothelial and neurovascular function in human skin microcirculation. Trends Pharmacol Sci 2013;34:373-84.

[9] Bouskela E, Grampp W. Spontaneous vasomotion in hamster cheek pouch arterioles in varying experimental conditions. Am J Physiol 1992;262:H478-85. 
[10] Jonk AM, Houben AJ, Schaper NC, de Leeuw PW, Serne EH, Smulders YM, et al. Obesity is associated with impaired endothelial function in the postprandial state. Microvasc Res 2011;82:423-9.

[11] de Haan CH, van Dielen FM, Houben AJ, de Leeuw PW, Huvers FC, De Mey JG, et al. Peripheral blood flow and noradrenaline responsiveness: the effect of physiological hyperinsulinemia. Cardiovasc Res 1997;34:192-8.

[12] Clerk LH, Vincent MA, Jahn LA, Liu Z, Lindner JR, Barrett EJ. Obesity blunts insulin-mediated microvascular recruitment in human forearm muscle. Diabetes 2006;55:1436-42.

[13] Houben AJHM, Burgwinkel JP, de Leeuw PW. A novel approach to the study of human microcirculation: reactivity to locally applied angiotensin II in the conjunctival microvascular bed. J Hypertens 2006;24: 2225-30.

[14] Sullivan JM, Prewitt RL, Josephs JA. Attenuation of the microcirculation in young patients with high-output borderline hypertension. Hypertension 1983;5:844-51.

[15] Houben AJ, Canoy MC, Paling HA, Derhaag PJ, de Leeuw PW. Quantitative analysis of retinal vascular changes in essential and renovascular hypertension. J Hypertens 1995;13:1729-33.

[16] Cheung CY-l, Ikram MK, Sabanayagam C, Wong TY. Retinal microvasculature as a model to study the manifestations of hypertension. Hypertension 2012;60:1094-103.

[17] Hughes AD. Genetic and early life influences on the human retinal microcirculation. Basic Clin Pharmacol Toxicol 2012;110:19-25.

[18] Thom S, Stettler C, Stanton A, Witt N, Tapp R, Chaturvedi $\mathrm{N}$, et al. Differential effects of antihypertensive treatment on the retinal microcirculation: an anglo-scandinavian cardiac outcomes trial substudy. Hypertension 2009;54: 405-8.

[19] Minson CT, Berry LT, Joyner MJ. Nitric oxide and neurally mediated regulation of skin blood flow during local heating. J Appl Physiol 2001;91:1619-26.

[20] Wolinsky H. A proposal linking clearance of circulating lipoproteins to tissue metabolic activity as a basis for understanding atherogenesis. Circ Res 1980;47:301-11.

[21] Stehouwer CD. Is measurement of endothelial dysfunction clinically useful. Eur J Clin Invest 1999;29:459-61.

[22] Kubes P, Kerfoot SM. Leukocyte recruitment in the microcirculation: the rolling paradigm revisited. News Physiol Sci 2001;16:76-80.

[23] Stehouwer CDA. Endothelial dysfunction in diabetic nephropathy: state of the art and potential significance for non-diabetic renal disease. Nephrol Dial Transplant 2004;19:778-81.

[24] Stehouwer CD, Lambert J, Donker AJ, van Hinsbergh VW. Endothelial dysfunction and pathogenesis of diabetic angiopathy. Cardiovasc Res 1997;34:55-68.

[25] Kasprzak JD, Klosinska M, Drozdz J. Clinical aspects of assessment of endothelial function. Pharmacol Rep 2006;58(Suppl.):33-40.

[26] Jensen T, Bjerre-Knudsen J, Feldt-Rasmussen B, Deckert T. Features of endothelial dysfunction in early diabetic nephropathy. Lancet 1989;1:461-3.

[27] Ochodnicky P, Henning RH, van Dokkum RPE, de Zeeuw D. Microalbuminuria and endothelial dysfunction: emerging targets for primary prevention of end-organ damage. J Cardiovasc Pharmacol 2006;47(Suppl. 2):S151-62. discussion S72-6.

[28] Stehouwer CDA, Smulders YM. Microalbuminuria and risk for cardiovascular disease: analysis of potential mechanisms. J Am Soc Nephrol 2006;17:2106-11.

[29] Newman JMB, Dwyer RM, St-Pierre P, Richards SM, Clark MG, Rattigan S. Decreased microvascular vasomotion and myogenic response in rat skeletal muscle in association with acute insulin resistance. J Physiol 2009;587:2579-88.

[30] Vincent MA, Barrett EJ, Lindner JR, Clark MG, Rattigan S. Inhibiting NOS blocks microvascular recruitment and blunts muscle glucose uptake in response to insulin. Am J Physiol Endocrinol Metab 2003;285:E123-9.

[31] Baron AD, Steinberg H, Brechtel G, Johnson A. Skeletal muscle blood flow independently modulates insulinmediated glucose uptake. Am J Physiol 1994;266:E248-53.

[32] Laakso M, Edelman SV, Brechtel G, Baron AD. Decreased effect of insulin to stimulate skeletal muscle blood flow in obese man. A novel mechanism for insulin resistance. J Clin Invest 1990;85:1844-52.

[33] Zhang L, Vincent MA, Richards SM, Clerk LH, Rattigan S, Clark MG, et al. Insulin sensitivity of muscle capillary recruitment in vivo. Diabetes 2004;53:447-53.

[34] Yki-Jarvinen H, Utriainen T. Insulin-induced vasodilatation: physiology or pharmacology. Diabetologia 1998;41:369-79.

[35] Clark MG, Wallis MG, Barrett EJ, Vincent MA, Richards SM, Clerk LH, et al. Blood flow and muscle metabolism: a focus on insulin action. Am J Physiol Endocrinol Metab 2003;284:E241-58.

[36] Vincent MA, Clerk LH, Lindner JR, Klibanov AL, Clark MG, Rattigan S, et al. Microvascular recruitment is an early insulin effect that regulates skeletal muscle glucose uptake in vivo. Diabetes 2004;53:1418-23.

[37] Kim J-a, Montagnani M, Koh KK, Quon MJ. Reciprocal relationships between insulin resistance and endothelial dysfunction: molecular and pathophysiological mechanisms. Circulation 2006;113:1888-904.

[38] Potenza MA, Addabbo F, Montagnani M. Vascular actions of insulin with implications for endothelial dysfunction. Am J Physiol Endocrinol Metab 2009;297:E568-77.

[39] Vincent MA, Dawson D, Clark ADH, Lindner JR, Rattigan S, Clark MG, et al. Skeletal muscle microvascular recruitment by physiological hyperinsulinemia precedes increases in total blood flow. Diabetes 2002;51:42-8.

[40] Wang H, Wang AX, Barrett EJ. Insulin-induced endothelial cell cortical actin filament remodeling: a requirement for trans-endothelial insulin transport. Mol Endocrinol 2012;26:1327-38.

[41] Johansson GS, Chisalita SI, Arnqvist HJ. Human microvascular endothelial cells are sensitive to IGF-I but resistant to insulin at the receptor level. Mol Cell Endocrinol 2008;296:58-63.

[42] Wong TY, Klein R, Sharrett AR, Schmidt MI, Pankow JS, Couper DJ, et al. Retinal arteriolar narrowing and risk of diabetes mellitus in middle-aged persons. JAMA 2002;287:2528-33.

[43] Kim F, Pham M, Maloney E, Rizzo NO, Morton GJ, Wisse BE, et al. Vascular inflammation, insulin resistance, and reduced nitric oxide production precede the onset of peripheral insulin resistance. Arterioscler Thromb Vasc Biol 2008;28:1982-8.

[44] de Jongh RT, Serne EH, Ijzerman RG, de Vries G, Stehouwer CDA. Free fatty acid levels modulate microvascular function: relevance for obesity-associated insulin resistance, hypertension, and microangiopathy. Diabetes 2004;53:2873-82.

[45] de Jongh RT, Ijzerman RG, Serne EH, Voordouw JJ, Yudkin JS, de Waal HAD-v, et al. Visceral and truncal subcutaneous adipose tissue are associated with impaired capillary recruitment in healthy individuals. J Clin Endocrinol Metab 2006;91:5100-6.

[46] Scalia R. The microcirculation in adipose tissue inflammation. Rev Endocr Metab Disord 2013;14:69-76.

[47] Bakker W, Sipkema P, Stehouwer CDA, Serne EH, Smulders YM, van Hinsbergh VWM, et al. Protein kinase C theta 
activation induces insulin-mediated constriction of muscle resistance arteries. Diabetes 2008;57:706-13.

[48] Yudkin JS, Eringa E, Stehouwer CDA. Vasocrine signalling from perivascular fat: a mechanism linking insulin resistance to vascular disease. Lancet 2005;365:1817-20.

[49] Eringa EC, Bakker W, van Hinsbergh VWM. Paracrine regulation of vascular tone, inflammation and insulin sensitivity by perivascular adipose tissue. Vascul Pharmacol 2012;56:204-9.

[50] Meijer RI, Bakker W, Alta C-LAF, Sipkema P, Yudkin JS, Viollet $\mathrm{B}$, et al. Perivascular adipose tissue control of insulin-induced vasoreactivity in muscle is impaired in $\mathrm{db} /$ db mice. Diabetes 2013;62:590-8.

[51] Rizzoni D, Agabiti-Rosei E. Structural abnormalities of small resistance arteries in essential hypertension. Intern Emerg Med 2012;7:205-12.

[52] Serne EH, Stehouwer CD, ter Maaten JC, ter Wee PM, Rauwerda JA, Donker AJ, et al. Microvascular function relates to insulin sensitivity and blood pressure in normal subjects. Circulation 1999;99:896-902.

[53] Greene AS, Tonellato PJ, Lui J, Lombard JH, Cowley Jr AW. Microvascular rarefaction and tissue vascular resistance in hypertension. Am J Physiol 1989;256:H126-31.

[54] Debbabi H, Uzan L, Mourad JJ, Safar M, Levy BI, Tibirica E. Increased skin capillary density in treated essential hypertensive patients. Am J Hypertens 2006;19:477-83.

[55] Hedman A, Reneland R, Lithell HO. Alterations in skeletal muscle morphology in glucose-tolerant elderly hypertensive men: relationship to development of hypertension and heart rate. J Hypertens 2000;18:559-65.

[56] Antonios TF, Singer DR, Markandu ND, Mortimer PS, MacGregor GA. Rarefaction of skin capillaries in borderline essential hypertension suggests an early structural abnormality. Hypertension 1999;34:655-8.

[57] Antonios TFT, Rattray FM, Singer DRJ, Markandu ND, Mortimer PS, MacGregor GA. Rarefaction of skin capillaries in normotensive offspring of individuals with essential hypertension. Heart 2003;89:175-8.

[58] Ijzerman RG, van Weissenbruch MM, Voordouw JJ, Yudkin JS, Serne EH, Delemarre-van de Waal HA, et al. The association between birth weight and capillary recruitment is independent of blood pressure and insulin sensitivity: a study in prepubertal children. J Hypertens 2002;20:1957-63.

[59] Ikram MK, de Jong FJ, Vingerling JR, Witteman JCM, Hofman A, Breteler MMB, et al. Are retinal arteriolar or venular diameters associated with markers for cardiovascular disorders? The rotterdam study. Invest Ophthalmol Vis Sci 2004;45:2129-34.

[60] Ikram MK, Witteman JCM, Vingerling JR, Breteler MMB, Hofman A, de Jong PTVM. Retinal vessel diameters and risk of hypertension: the rotterdam study. Hypertension 2006;47:189-94.

[61] Smith W, Wang JJ, Wong TY, Rochtchina E, Klein R, Leeder $\mathrm{SR}$, et al. Retinal arteriolar narrowing is associated with 5year incident severe hypertension: the blue mountains eye study. Hypertension 2004;44:442-7.

[62] Wong TY, Klein R, Sharrett AR, Duncan BB, Couper DJ, Klein $\mathrm{BEK}$, et al. Retinal arteriolar diameter and risk for hypertension. Ann Intern Med 2004;140:248-55.

[63] Lasta M, Polak K, Luksch A, Garhofer G, Schmetterer L. Effect of NO synthase inhibition on retinal vessel reaction to isometric exercise in healthy humans. Acta Ophthalmol 2012;90:362-8.

[64] Nagel E, Vilser W, Lanzl I. Age, blood pressure, and vessel diameter as factors influencing the arterial retinal flicker response. Invest Ophthalmol Vis Sci 2004;45: 1486-92.

[65] Rossi M, Bradbury A, Magagna A, Pesce M, Taddei S, Stefanovska A. Investigation of skin vasoreactivity and blood flow oscillations in hypertensive patients: effect of short-term antihypertensive treatment. J Hypertens 2011;29:1569-76.

[66] Rossi M, Nannipieri M, Anselmino M, Pesce M, Muscelli E, Santoro G, et al. Skin vasodilator function and vasomotion in patients with morbid obesity: effects of gastric bypass surgery. Obes Surg 2011;21:87-94.

[67] Jacobsen JCB, Holstein-Rathlou N-H. A life under pressure: circumferential stress in the microvascular wall. Basic Clin Pharmacol Toxicol 2012;110:26-34.

[68] Renna NF, de Las Heras N, Miatello RM. Pathophysiology of vascular remodeling in hypertension. Int J Hypertens 2013;2013:808353.

[69] Bakker ENTP, Buus CL, VanBavel E, Mulvany MJ. Activation of resistance arteries with endothelin-1: from vasoconstriction to functional adaptation and remodeling. J Vasc Res 2004;41:174-82.

[70] Feihl F, Liaudet L, Waeber B. The macrocirculation and microcirculation of hypertension. Curr Hypertens Rep 2009;11:182-9. 